\title{
Gradiva non vixit albo życie z duchami
}

\author{
Adam Lipszyc
}




\section{Interpretacje}

\section{Gradiva non vixit albo życie z duchami}

Adam Lipszyc

TEKSTY DRUGIE 2017, NR 4, S. 166-186

DOI: $10.18318 /$ td.2017.4.11

W Widmach Marksa Jacques Derrida stawia tezę, że autor Manifestu komunistycznego był wielkim specjalistą od duchów ${ }^{1}$. Derrida wskazuje, jak często figura widma nawiedza teksty Marksa: gdy mowa o widmie komunizmu, o widmie dawnych rewolucji, o widmowym charakterze towaru. Stosunek Marksa do widm jest, przynajmniej nominalnie, stosunkiem egzorcysty: filozof zna się na nich, ale po to, by się ich pozbyć. Cieszy go oczywiście, że europejskie potęgi drżą ze strachu przed widmem komunizmu, chciałby jednak, żeby widmo to stało się ciałem; zamiast repetytywnych widm dawnych rewolucji chętnie widziałby rewolucyjnego, zwróconego ku przyszłości ducha; wysiłek tej właściwej rewolucji prowadziłby zaś do takiej przemiany stosunków społeczno-ekonomicznych, dzięki której przedmioty uwolniłyby się od dręczących je widm utowarowienia, każących brać wartość wymienną za wartość użytkową.

\section{Adam Lipszyc}

(ur. 1975) - eseista i tłumacz, pracuje w Instytucie Filozofii i Socjologii PAN, uczy w Szkole Nauk Społecznych, w Collegium Civitas oraz na Uniwersytecie Muri im. Franza Kafki. Ostatnio opublikował książkę Czas wiersza. Paul Celan i teologie literackie (2015). Kontakt:adamlipszyc@ gmail.com

1 Zob. J. Derrida Widma Marksa, przeł. T. Załuski, PWN, Warszawa 2016. 
Samego Derridę z kolei cieszy Marksowska fascynacja widmami, nie cieszą go wszakże jego egzorcystyczne ambicje. Egzorcyzmy, które planuje Marks, są niewykonalne: by wziąć przykład bodaj najważniejszy, nie ma czystego ducha rewolucji, który nie byłby skontaminowany przez widma przeszłości. Egzorcyzmy te jednak nie są też wcale pożądane: wyegzorcyzmowanie widma rewolucji może polegać albo na utwierdzeniu i utwardzeniu ideologicznego przekonania, że gospodarka kapitalistyczna nie wymaga korekty w imię sprawiedliwości; albo na faszystowskiej mobilizacji wokół ideologii narodowej; albo wreszcie na przeobrażeniu widma rewolucji w upiora totalitarnego państwa i partyjnej ideologii opartej na wierze w konieczność historyczną. Tak czy inaczej, kończy się to źle. Tymczasem prawdziwy duch rewolucji widmem być musi i jako widmo winien bezustannie nawiedzać kapitalistyczną Europę, raz po raz otwierając ją na utopię sprawiedliwości i demokracji, która nadchodzi. Co więcej i co może najważniejsze, to właśnie pozwalając temu widmu nieustannie powracać, nie zaś przeobrażając je w upiora totalitarnej machiny, pozostajemy dziś wiernymi-niewiernymi dziedzicami Karola Marksa.

Wstęp do książki rozpoczyna Derrida od wzmianki o człowieku, który chciałby wreszcie nauczyć się żyć. Nauka życia, a nie samo życie - rozumuje Derrida - musi odbywać się między życiem a śmiercią, w sferze pośredniej, a zatem w sferze widm. Trzeba zatem nauczyć się żyć z widmami, mówić o widmach, a nawet do widm². Trzeba stać się „innym uczonym”, który toleruje te nigdy nie w pełni obecne twory, jakim są widma ${ }^{3}$. Twory nie w pełni obecne, a zarazem nie w pełni teraźniejsze: wedle Derridy zasadniczą cechą widm jest to, że dezorganizują temporalny wymiar naszego życia, wprowadzają doń żywioł anachroniczności, który sprawia, że żyjemy nagabywani przez różne momenty czasowe, fragmenty nawracającej przeszłości i oczekiwania na to, co może nadejść ${ }^{4}$. To właśnie powoduje, że - jak trafnie zauważył Jakub Momro, dyrektor Archiwum Negatywności przy Uniwersytecie Muri im. Franza Kafki - niepełna obecność widm nie oznacza słabości ich istnienia. Wręcz przeciwnie: interwencja widm, łącząca naszą teraźniejszość z jakimś innym momentem czasowym w sposób zawsze nacechowany afektywnie, jest doświadczeniem dojmującym, przed którym rzadko potrafimy się

\footnotetext{
2 Tamże, s. 11-13.

3 Tamże, s. 34 .

4 Tamże, s. 25-26, 48-49, 187-188.
} 
uchylić. Jeśli zaś Marks wskazał i opisał całą kohortę widm, które nawiedzają współczesne życie, za wszelką cenę wszakże starał się je wyegzorcyzmować w imię ideału życia nieskontaminowanego i stabilnej temporalności, a może nawet kresu dziejów, to Derrida dowodzi, że godny dziedzic Marksa uczy się żyć z widmami w trybie nieusuwalnej anachronii. Co bodaj najważniejsze, nawiedzenie przez anachronizujące widma byłoby wręcz definicyjnym wyróżnikiem każdego pojedynczego, skończonego życia ${ }^{5}$.

Derrida pokazuje przekonująco, że taka spektralna, anachronizująca filozofia życia umożliwia świeże i atrakcyjne odczytanie Marksowskiego dzieła. Gdyby jednak ktoś zechciał rozwinąć nieco samą tę filozofię, nie wydaje się, by inspiracji powinien szukać przede wszystkim w tekstach Marksa. Lepiej chyba zajrzeć do autorów, których bardziej ciekawi pojedyncze życie. Choćby do takiego Freuda. Zachęcić nas mógłby do tego fakt, że sam Derrida zwraca uwagę, iż ojciec psychoanalizy odnosi się do widm w podobny sposób co Marks. W książce o „gorączce archiwum” mówi wprost: „Wiadomo, że Freud robił wszystko, by nie zlekceważyć doświadczeń nawiedzenia, widmowości, zjaw, duchów. Starał się je uwzględnić. Odważnie, w sposób naukowy, krytyczny i pozytywny, tak jak tylko było to możliwe. Ale czyniąc to, starał się je również poddać egzorcyzmom. Tak jak Marks. Jego naukowy pozytywizm służył jego zadeklarowanej obsesji oraz nieujawnionemu lękowi"6. Nieco dalej Derrida pokazuje w telegraficznym skrócie, jak w przypadku Freuda wygląda owo zamawianie. Terapia psychoanalityczna miałaby być w istocie egzorcyzmem, ponieważ stara się uciszyć i przegnać widma, a to dzięki temu, że dopuści je do głosu, a zarazem prześledzi ich pochodzenie, tym samym zaś - je wyeliminuje. Freud wie, do jakiego stopnia nasze życie jest życiem z widmami, lecz, mówi Derrida, na koniec „egzorcyzmuje widma. [...] Wierzy, że wyegzorcyzmował zjawy w chwili, gdy pozwolił im mówić, pod warunkiem, że widma mówią, jak sądzi Freud, w sposób metaforyczny"7.

Gdy na ostatnich stronach rozprawy o „gorączce archiwum” Derrida podejmuje temat widm w dziele Freuda, odnosi się przede wszystkim do eseju poświęconego Gradivie Wilhelma Jensena. Wybór jest oczywisty, bo to właśnie w tym tekście Freud w sposób szczególnie jawny konfrontuje się z tematyką spektralną. Te końcowe partie książki o archiwum są jednak nader

5 Tamże, s. 181.

6 J. Derrida Gorq̨czka archiwum. Impresja freudowska, przeł. J. Momro, Wydawnictwo IBL PAN, Warszawa 2016, s. 125.

7 Tamże, s. 139. 
rozczarowujące: Derrida żongluje cytatami i formułami, nie przeprowadza jednak solidnej analizy, a co dopiero płodnej dekonstrukcji Freudowskiego eseju. Proponuję zatem sprawdzić, jak mogłoby wyglądać takie odczytanie, podjęte w duchu Derridy. Wcześniej jednak chciałbym jeszcze rzucić okiem na inny tekst Freuda, a mianowicie na analizę pewnego snu podjętą w Objaśnianiu marzeń sennych. Zarówno w tej analizie, jak i w eseju o Gradivie Freud zajmuje się widmami, na koniec zaś wydaje mu się, że się z nimi uporał, tymczasem - jak postaram się pokazać - chyba tak wcale nie jest. Jeśli zaś odsłonięcie w tekście obecności subwersywnych, nieprzewidzianych przez autora momentów spektralnych można uznać za jedną z definicji dekonstrukcji, to proponuję taką właśnie dekonstrukcyjną lekturę tych dwóch tekstów, mając nadzieję, że takie odczytanie choć trochę wzbogaci, dookreśli i skomplikuje ową spektralną, anachroniczną filozofię życia, której zrąb zarysowuje Derrida w Widmach Marksa.

Idzie mianowicie o sen, który Freud omawia dwukrotnie, po kawałku, pozwalając temu marzeniu o widmach w iście widmowy sposób powrócić w obrębie jednego, a dokładnie szóstego rozdziału książki, który dotyczy pracy marzenia sennego. Marzenie to zostaje przywołane najpierw w podrozdziale, w którym Freud przygląda się przypadkom mówienia we śnie ${ }^{8}$. Dla uproszczenia przytaczam tylko fragment zapisu tego snu. Oto śniący Freud siedzi przy stole ze swoim przyjacielem Wilhelmem Fliessem oraz z nieżyjącym już lekarzem Josefem Panethem (ci dwaj pojawiają się w tekście, odpowiednio, jako Fl. i P.). Fliess pyta Freuda, co opowiedział Panethowi o śmierci jego, Fliessa, siostry. Czytamy: „Ja na to, ogarnięty osobliwymi afektami, chcę poinformować Fl., że P. [przecież nie może tego wiedzieć], ponieważ nie żyje. Mówię jednak, samemu spostrzegając pomyłkę: «Non vixit» [czyli «Nie żył» zamiast «Nie żyje» - A.L.]. Następnie przeszywam P. spojrzeniem, pod jego wpływem P. blednie, rozmywa się, jego oczy stają się chorobliwie niebieskie - i w końcu roztapia się w powietrzu. Niezwykle się z tego cieszę, teraz rozumiem, że i Ernst Fleischl [nieżyjący profesor, który pojawiał się we wcześniejszej partii snu] to tylko zjawa, widmo [revenant], i uważam, że to zupełnie możliwe, iż taka osoba istnieje tylko dopóty, dopóki człowiek tego chce, i że wystarczy pragnienie [Wunsch], by przestała istnieć"

W tym pierwszym podejściu do owego marzenia Freud wysypuje na stół garść nader intrygujących wspomnień, skojarzeń i sugestii interpretacyjnych.

8 Zob. S. Freud Objaśnianie marzeń sennych, przeł. R. Reszke, KR, Warszawa 1996, s. 359-362.

9 Tamże, s. 360. Przekład skorygowany. 
Po pierwsze, tłumaczy, że przeszywające spojrzenie, jakim we śnie obdarza widmo Panetha, to introjektowane spojrzenie błękitnych oczu profesora Brückego, także już nieżyjącego i również wspomnianego w początkowej partii snu mentora, który skarcił niegdyś Freuda za spóźnienie do laboratorium, świdrując go przy tym wzrokiem. Po drugie, stwierdza, że choć słowa non vixit są w tym miejscu nieadekwatne, posłużył się nimi, zaczerpnąwszy je z napisu na pewnym wiedeńskim pomniku ku czci cesarza (pełny napis celebruje krótkie, lecz chwalebne życie władcy). Po trzecie, utrzymuje, że w tym śnie wyraża się jego ambiwalentny stosunek do Panetha, któremu zarówno wystawia pomnik, jak i go niszczy. Ta formuła, po czwarte, kojarzy mu się z pewną kwestią Szekspirowskiego Juliusza Cezara, w której w podobnie ambiwalentny sposób Brutus wypowiada się o tytułowej postaci. Identyfikacja z Brutusem pozwala wreszcie Freudowi, po piąte, wykonać krok najbardziej zaskakujący: ojciec psychoanalizy przypomina sobie mianowicie, że jako dziecko grał kiedyś Brutusa. Cezara odgrywał wówczas niejaki John, niegdysiejszy towarzysz zabaw dziecięcych, który przyjechał właśnie z Anglii, a więc - mówi Freud - „i on był revenant" ${ }^{\prime \prime}$. W owym non vixit niestrudzony interpretator dosłuchuje się ostatecznie słowa wichsen (sprać) i dalekiego echa sceny, podczas której jako mały chłopiec tłumaczył się przed ojcem, że sprał Johna, bo i on go sprał. To owo wichsen miało wymusić zmianę poprawnego vivit na vixit. Freud stwierdza przy tym otwarcie (i już po raz drugi w tej książce), że relacja z owym Johnem - nieco starszym od niego synem jego przyrodniego brata - stanowi dlań wzorzec wszystkich późniejszych relacji z mężczyznami, naznaczonych głębokim przywiązaniem lub gwałtowną nienawiścią, często zaś jednym i drugim. Zapewne kluczowym przykładem byłaby tutaj relacja z Wilhelmem Fliessem, choć w tym akurat marzeniu sennym - bodaj mocą przemieszczenia - rolę Johna odgrywa znacznie mniej dla Freuda istotny Josef Paneth ${ }^{11}$.

Warto zauważyć, że pierwsza wzmianka o relacji z Johnem pojawia się w Objaśnianiu marzeń sennych na zakończenie passusu, gdzie Freud opowiada o swojej dziecięcej fascynacji Hannibalem jako semickiem wodzem, który pokonał Rzym, potęgę utożsamianą przez małego Freuda z katolicyzmem i żywiołem antysemickiej opresji. Jak relacjonuje Freud, w dzieciństwie słuchał z zażenowaniem opowieści ojca o antysemickiej napaści, na którą ojciec nie mógł czy nie potrafił zareagować, musiał więc znieść ją w milczeniu. Tej upokarzającej scenie przeciwstawiał mały Sigmund „scenę, w której Hamikar Barkas, ojciec Hannibala, każe mu przysiąc przed ołtarzem, że zemści się na Rzymianach”. W tym właśnie kontekście czytamy: „Być może proces rozwoju tej idei wojownika dałoby się prześledzić sięgając jeszcze dalej wstecz w lata dzieciństwa, do życzeń wynikających z już to przyjaznego, już to wojowniczego obcowania z o rok starszym chłopcem - do życzeń wynikających ze słabszej pozycji młodszego z dwojga 
Sen o non vixit powraca na koniec części rozdziału szóstego poświęconej afektom w marzeniu sennym. Zgodnie z tą lokalizacją Freud podejmuje tutaj próbę odsłonięcia afektywnego wymiaru tego marzenia. Wobec faktu, że bezpośrednią pobudką snu była wiadomość o operacji, jakiej poddany został Fliess, jest w tym śnie lęk, że przyjaciel umrze, oraz lęk, że on, Freud, spóźni się z odwiedzinami u chorego, tak jak spóźniał się do laboratorium, za co profesor karcił go przeszywającym spojrzeniem. Do tych lęków dołączają niepokoje Freuda związane z zarzutami o niedyskrecję, jakie czynił mu niegdyś Josef Breuer. Marzenie senne miałoby łączyć dwa wstydliwe elementy (spóźnialstwo i niedyskrecja), lecz mając na uwadze spełnienie pragnień, dokonywałoby sprytnego odwrócenia, w wyniku którego to śniący unicestwia wzrokiem pewnego Josefa (a mianowicie Panetha).

Zdaniem Freuda afekty te uzyskują jednak wzmocnienie z głębszych źródeł, z samego afektywnego rdzenia tego snu. Zgodnie ze wstępnymi uwagami sformułowanymi w ramach pierwszego podejścia do tego marzenia rdzeń ów wiąże się z postacią Johna. Freud raz jeszcze stwierdza, że wszystkie jego relacje z rówieśnikami wywodzą się z tego pierwotnego związku, że - to jego słowa - „wszyscy moi przyjaciele w pewnym sensie stanowią wcielenia tej pierwszej postaci, która [to cytat z Fausta] «ukazała się zmąconym oczom» to zjawy [revenants]"12. Wywoławszy raz jeszcze widmo Johna, Freud zapuszcza się w otchłanie pamięci i wydobywa z nich scenę, która stała się przyczyną

rodzeństwa" (S. Freud Objaśnianie marzeń sennych, s. 180). Co ciekawe, w jednym z przypisów do książki o Mojżeszu Freud powraca do związku między Johnem i Hannibalem, tak ważną dla siebie relację skrywając tym razem za zasłoną chwiejnych rozważań etymologicznych. Pisze tutaj: „Utworzone ze skrócenia imienia boskiego [Jahwe] hebrajskie imię Johanan (znaczące tyle, co niemieckie Gotthold, którego punickim odpowiednikiem jest Hannibal) stało się ulubionym imieniem europejskiego chrześcijaństwa, gdzie przybrało takie formy, jak Johann, John, Juan" (S. Freud Człowiek imieniem Mojżesz a religia monoteistyczna, przeł. A. Ochocki, R. Reszke, W: tegoż Pisma społeczne, opr. R. Reszke, KR, Warszawa 1998, s. 422). W jednym szeregu znajdują się tutaj zatem podziwiani mocarze: Jahwe, Hannibal i John. A jednak - mocą zrozumiałej ambiwalencji - w kontekście snu o non vixit podziwiany John występuje w roli Juliusza Cezara, z którym rywalizuje Brutus-Sigmund (młodszy brat, przybrany syn i morderca zarazem). Rola, jaką John odgrywa w Objaśnianiu marzeń sennych, potwierdza ogólną tezę Juliet Mitchell, według której psychoanaliza na poziomie materiału analitycznego i szczegółowych analiz często stykała się z problematyką horyzontalnych relacji między rodzeństwem - dotykając przy tym nader ważkich kwestii związanych z konstytucją podmiotowości - by następnie na poziomie teorii w znacznym stopniu zatracić tę perspektywę i podporządkować ją wertykalnym relacjom dziecko - ojciec, w późniejszym okresie zaś (przede wszystkim u Melanie Klein i Donalda Winnicotta) dziecko - matka. Zob. J. Mitchell Siblings, Polity, Oxford 2003. 
bójki, owego Wichsen między chłopcami i tłumaczeń przed trybunałem (niezbyt zresztą groźnego) ojca/dziadka, Jacoba Freuda: obaj mieli spieszyć wówczas do jakiegoś upragnionego obiektu, a młodszy, Sigmund, niczym biblijny Jakub bezprawnie uparł się przy swoim pierwszeństwie. Z tej sceny pierwotnej, którą Freud przedstawia jako buzujące afektywne źródło marzenia sennego, wypływać mają wszystkie zmieszane uczucia ów sen kształtujące. Ostatecznie miałyby się one sprowadzać do rozmaitych, arcyegoistycznych, a zarazem sprzecznych satysfakcji. Z jednej strony Freuda miałoby cieszyć, że konkurent (John, Paneth, Fliess) został lub zostanie ukarany śmiercią za dążenie do pierwszeństwa i że on, Sigmund, przeżył śmierć kolejnego konkurenta, ba, ponieważ wszyscy oni to tylko widma, on sam potrafi ich likwidować swoim wszechmocnym wzrokiem. $Z$ drugiej strony jednak satysfakcja miałaby płynać z odkrycia, że wciąż pojawiają się nowe wcielenia dawnego towarzysza zabaw, że Zygmunt może sobie powiedzieć: „Nie ma ludzi niezastąpionych. Spójrz, to tylko zjawy; wszystko, co zostało stracone, powraca znowu"13. Na koniec, dzięki rozmaitym zbieżnościom imion osób i krewnych osób uwikłanych w tę senną historię, Freud odsłania jeszcze jedno źródło tego rodzaju satysfakcji: „Stąd nić myśli biegnie do imion, jakie nadałem własnym dzieciom. Obstawałem, by nie wybierać ich podług obowiązującej właśnie mody, lecz by kierować się w tym pamięcią drogich osób. To właśnie ich imiona sprawiają, że dzieci stają się zjawami. No i wreszcie: czyż posiadanie dzieci nie jest dla nas wszystkich jedynym sposobem osiągnięcia nieśmiertelności?"14.

Przedstawiając swój sen i jego interpretację, Freud prezentuje się jako prawdziwy ekspert od widm. Wywołuje legion duchów, by następnie podjąć próbę ich okiełznania. Pozorując prawdziwie naukową szczerość, która każe mu się przyznać do najpotworniejszego egoizmu wobec przyjaciół, ocala zarówno swoje spoiste, kalkulujące Ja, jak i linearny porządek czasu, w którym owo Ja się porusza. Oto, począwszy od źródłowej sceny z Johnem-prawzorcem, w kolejnych okresach swojego życia miałby napotykać przyjaciół-konkurentów, którzy rytmicznie pojawiają się i znikają jako swoje kolejne wcielenia; w szerszym planie linearny ład czasu zostaje zaś podtrzymany dzięki regularnemu następstwu pokoleń. Wobec tak zidentifikowanego punktu źródłowego oraz uporządkowanego rytmu wcieleń i generacji spektralny charakter tych widm staje się doprawdy czysto metaforyczny, mamy tu bowiem 
do czynienia raczej z następstwem kolejnych, całkiem żywych obecności obserwowanych przez skończone, ale wewnętrznie spójne, żywe Ja.

A przecież sprawa nie jest tak prosta. Dokładnie tak jak uczy Derrida: widma raz wywołane nie dają się tak łatwo schować do przegródek i wprowadzają anachroniczne zamieszanie. Zwróćmy uwagę na trzy elementy tej historii, które Freud przemilcza, a przynajmniej wycisza. Po pierwsze, jest rzeczą osobliwą, że Freud kładzie tak wielki nacisk na zbawienne następstwo pokoleń w kontekście narracji, której jądro wyznacza relacja z towarzyszem owo następstwo tak dotkliwie zaburzającym: John pochodzi z następnego pokolenia, ale jest nieco starszy od Sigmunda, a zarazem ma prefigurować jego relacje z rówieśnikami. Nie jest ani postacią ojcowską, jednoznacznie wcześniejszą, ani synowską, jednoznacznie późniejszą, tylko jego Drugim, konkurentem do obiektu pragnienia, a może nawet konkurentem w istnieniu jako takim, dziwnym, symultanicznym-lecz-anachronicznym sobowtórem. Po drugie, John, prawzór wszystkich relacji z rówieśnikami, nie jest wcale żywą obecnością, trwałym i niepodzielonym źródłem późniejszych wcieleń. Sam Freud nazywa go widmem, tak więc - ściśle rzecz biorąc - późniejsi przyjaciele ojca psychoanalizy są widmami pewnego widma. Aby zagrać Juliusza Cezara, John musiał bowiem powrócić z Anglii i ożywić wspomnienia jeszcze wcześniejszego dzieciństwa. Ten najwcześniejszy punkt jednak tonie w mroku niejasności: gdy Freud przedstawia ową pierwotną scenę wyścigu do obiektu, przyznaje, że najprawdopodobniej jest to fantazja. Posługując się kategorią, którą Freud miał wypracować dopiero nieco później, powiedzielibyśmy, że fantazja ta powstała zgodnie z logiką naznaczenia wstecznego: coś się tam wydarzyło, ale kształtu i skuteczności nabrało za sprawą późniejszych wypadków. Zwróćmy też uwagę, że przywołując cytat z Fausta, Freud mniej lub bardziej mimowolnie uznaje widmowy status źródłowego elementu całej serii. We fragmencie tym czytamy bowiem o schwankende Gestalten, chwiejnych kształtach, które ukazały się niegdyś mętnemu spojrzeniu, teraz zaś powracają: nie ma mowy o tym, by kiedyś były wyraźniejsze. Jak zresztą wkrótce zobaczymy, przyglądając się esejowi o Gradivie, jest rzeczą nader charakterystyczną, że w tym właśnie miejscu, w samym środku swego wywodu, Freud przywołuje na pomoc dyskurs literacki.

Po trzecie wreszcie, rozważenia domaga się centralna fraza snu: non vixit. Zwraca uwagę, że Freud w sposób nader uporczywy umyka przed zaskakującym, bezpośrednim jej znaczeniem. Wskazuje, że jawna treść snu wymagałaby wyrażenia non vivit. Upiera się też jednak, że - ponieważ w sekrecie fantazjuje, jak to przybiegnie spóźniony do szpitala i dowie się, że Fliess już 
nie żyje - wymagałaby tego również treść utajona. Tym, co miałoby wykoślawić frazę non vivit i przekształcić ją w non vixit, byłoby przebijające się z infantylnych pokładów psychiki wichsen, powiązane ze zmaganiami z Johnem. Czy jednak ta dziwna zgodność jawnej treści i tego, co Freud identyfikuje jako treść utajoną, nie powinna wzbudzać naszej czujności? Jest uderzające, że Freud, niczym cenzor i stróż temporalnego ładu, dokłada wszelkich starań, żeby wyeliminować owo niedorzeczne, zaburzające przyzwoitą temporalność non vixit, rozdzielić je i zastąpić je dorzecznym non vivit, odnoszącym się do współczesnego przyjaciela, oraz wichsen, odnoszącym się do ustalonego prawzorca, czyli Johna. A może wypadałoby jednak zatrzymać się przy dosłownym znaczeniu owego non vixit? Mogłoby ono mieć trzy rozbieżne czy zgoła sprzeczne, lecz komplementarne znaczenia. Jedno byłoby wyrazem triumfu: on nigdy nie żył, więc się nie spóźniłem. Drugie byłoby wyrazem żałoby: straciłem go i jest tak, jakby on nigdy nie żył. Trzecie wreszcie, najbardziej paradoksalne, oddawałoby szczególny status widma, które nie przestaje nawiedzać Freudowskiego Ja: on jest prawdziwie anachroniczny, nigdy nie było takiej chwili teraźniejszej, w której widmo było w pełni obecne, nigdy nie miało swojej żywej teraźniejszości. I właśnie jako takie będzie nieustannie powracać i nawiedzać tego, który chce żyć z teraźniejszości na teraźniejszość.

Te trzy momenty w znacznym stopniu kwestionują wizję spoistego podmiotu jednostkowego życia, który sunie miarowo przez linearny czas i w miłosno-nienawistnych zmaganiach napotyka kolejne wcielenia źródłowego towarzysza. Zamiast tego wyłania się obraz podmiotu, którego życie jest nieodłączne od prawdziwie anachronicznego nawiedzenia. Podmiot ów nękany jest bowiem przez niedo-ojcowskie, niedo-synowskie, zdesynchronizowane widmo niesamowitego konkurenta, który jest zarówno nieco wcześniejszy, jak i nieco późniejszy, który jest po trosze prekursorem i następcą i jako taki przebywa w jego teraźniejszości, ba, jako przedmiot nieustannie podejmowanej i nieustannie zrywanej identyfikacji - to ja przybiegłem pierwszy, to ja byłem tobą, nigdy nie jesteś dość odrębny ode mnie, ale też nigdy nie jesteś całkiem mną - instaluje się w obrębie samego podmiotu, spektralizując i desynchronizując jego tożsamość. Ostatecznie widmo Johna budzi grozę, ponieważ, nie pozwalając na ustanowienie spokojnego następstwa kolejnych pokoleń, ruguje podmiot z jego własnej teraźniejszości i kwestionuje jego suwerenność. Stąd też najogólniejszą lekcją historii z non vixit może być rozpoznanie zasadniczej niesuwerenności podmiotu żyjącego, jego źródłowego otwarcia na nawiedzenie przez to, co uprzednie i to, co nadchodzące - także na uprzednie i nadchodzące wersje samego podmiotu - na tego, który nigdy 
nie żył, lecz właśnie jako taki desynchronizuje wszelką teraźniejszość tego, któremu żyć przyszło.

Według Derridy jedną z charakterystycznych cech widma jest to, że potrafi ono wpatrywać się w nas dręczącym spojrzeniem, samo nigdy nie mogąc stać się w pełni obecnym przedmiotem oglądu ${ }^{15}$. Spojrzenie, którym Freud w swoim śnie unicestwia widmo Josefa Panetha i które - jak sam zaświadcza źródłowo było wymierzone w niego samego, byłoby więc efektem introjekcji spojrzenia widmowego. Ostatecznym celem tej introjekcji jest może nie tyle likwidacja tego czy innego pojawu, ile wyegzorcyzmowanie widmowości jako takiej, która nawiedza i spektralizuje podmiotowość uczonego. Ale znikając, widmo posyła nam jeszcze raz spojrzenie uderzająco niebieskich oczu, a tym samym obiecuje swój rychły powrót. A jeśli tak, to trzeba wreszcie nauczyć się żyć - z duchami. W tym zaś właśnie może nam dopomóc analiza eseju o Gradivie. O ile bowiem fragmenty o non vixit pozwalają uchwycić bazową strukturę podmiotu nieusuwalnie nawiedzonego, o tyle esej ten, zwłaszcza skonfrontowany z samą nowelką Wilhelma Jensena, której jest poświęcony, idzie znacznie dalej, pokazując, jak mogłoby wyglądać życie takiego podmiotu - i że niekoniecznie musiałoby być nieszczęśliwe.

Przypomnijmy pokrótce, w czym rzecz ${ }^{16}$. Gradiva to historia młodego archeologa, Norberta Hanolda, który pogrążony w badaniach nad starożytnością nie przejawia najmniejszego zainteresowania erotycznym wymiarem ludzkiego żywota. Tenże Hanold ulega fascynacji pewnym starożytnym reliefem: przedstawia on kroczącą kobietę, której prawa stopa układa się w niezwykle intrygujący sposób. Archeolog nadaje jej imię Gradiva („krocząca”) i podejmuje studia nad tym, czy kobiety istotnie mogą w ten sposób chodzić - okazuje się, że żadna z napotkanych niewiast w ten sposób stopy nie układa. Hanolda nawiedza sen, podczas którego archeolog znajduje się w Pompejach w chwili zagłady miasta, spotyka tam Gradivę, która układa się jakby do snu i kamienieje. Po przebudzeniu archeolog sądzi, że ujrzał przez okno Gradivę i wybiega z domu w niekompletnym stroju. Za sprawą owego snu utrwala się w nim przekonanie, że Gradiva żyła w Pompejach i zginęła podczas katastrofy, traktuje ją więc jako utraconą. Po jakimś czasie pod wpływem impulsu udaje się w podróż do Włoch, odwiedziwszy zaś Florencję, Rzym i Neapol, w których

15 J. Derrida Widma Marksa, s. 26.

16 Zob. W. Jensen Gradiva, w: W. Jensen, S. Freud Gradiva, przeł. R. Reszke, KR, Warszawa 2007, s. 7-79. Tekst oryginalny dostępny na stronie: http://www.gutenberg.org/files/36275/36275-h/36275-h.htm. 
nękają go muchy i niemieccy nowożeńcy, ostatecznie ląduje w Pompejach. Tam przydarza mu się coś bardzo dziwnego. W samo południe, w godzinę duchów, napotyka mianowicie Gradivę, która wszelako rozmawia z nim po niemiecku i przedstawia się jako Zoe. Hanold dochodzi do wniosku, że jest obłąkany. Kolejne spotkania i rozmowy obfitujące w detale, którymi Jensen operuje w sposób nader błyskotliwy, prowadzą jednak ostatecznie do likwidacji obłędu, rozwiązania zagadki i szczęśliwego finału. Zoe okazuje się córką profesora zoologii nazwiskiem Bertgang, sąsiadką Norberta, a zarazem jego przyjaciółką z dzieciństwa, którą archeolog - jak całą płeć kobiecą - porzucił wszakże na rzecz kamieni. To ją widział Norbert przez okno swojego mieszkania i to ona chodzi tak jak Gradiva. Zwracając się zatem ku Zoe, Hanold z niejakim opóźnieniem, lecz nader pomyślnie - rozpoczyna życie miłosne.

Esej Freuda ma nominalnie dotyczyć odpowiedzi na pytanie, czy wypracowane w Objaśnianiu marzeń sennych techniki interpretacji snów można odnieść do marzeń fikcyjnych postaci pojawiających się w dziełach literackich ${ }^{17}$. Wydaje się, że tak - rozumuje Freud - ponieważ podobnie jak psychoanalitycy, pisarze zdają się wierzyć w głębszą sensowność sennych narracji. Nowelka Jensena, obfitująca w marzenia senne nieszczęsnego archeologa, miałaby dostarczać poręcznego materiału do badań w tym względzie. Jednakże gwoli przypomnienia czytelnikowi fabuły nowelki, Freud streszcza ją bardzo dokładnie, a streszczenie to zajmuje mu cały pierwszy rozdział eseju. Co więcej, streszczenie to, choć bardzo szczegółowe i często inkrustowane sformułowaniami samego Jensena, nie jest wolne od momentów interpretacyjnych. Ba, Freud wprowadza tu już zasadnicze elementy swojej wykładni. Co jeszcze zabawniejsze, po tym szczegółowym, lecz już interpretacyjnie wyprofilowanym streszczeniu-powtórzeniu, w pozostałych trzech rozdziałach eseju Freud oferuje swoistą powtórkę tej powtórki: zamiast zabrać się za analizę samych tylko snów, raz jeszcze przechodzi wszystkie etapy narracji, opatrując je - jak sam mówi - „glosami”. Trudno oprzeć się wrażeniu, że za pomocą tych dwóch powtórzeń pragnie w interpretacyjnym geście zawładnąć historią Jensena. Istotnie, jakkolwiek Freud wychwala Jensena jako jego, Freuda, mimowolnego wspólnika w rozumieniu ludzkiej psychiki, mechanizmów obłędu i marzenia sennego, jest chyba o niego zazdrosny i stara mu się Gradivę - i Gradivę odebrać. Nie jest może przypadkiem, że cały esej zaczyna się od słów In einem Kreise von Männer..., czyli „W gronie mężczyzn...”. Oto dwóch facetów bieży do obiektu - do Gradivy - i próbuje nawzajem wydrzeć sobie pierwszeństwo.

Tamże, s. 81-168. Dalsze odniesienia do tego tomu w tekście, wraz z numerem strony. 
Pisarz jest Johnem psychoanalityka. Literatura nawiedza dyskurs psychoanalityczny, jest przed nim i po nim, otwiera go i niepokoi, czyni głęboko niestabilnym, a przez to żywym i fascynującym. Ostatecznie zapewne literatura bierze górę, lecz zwycięstwo nie należy do autora, a do jego postaci: po trosze do Norberta, to przecież on dostaje swoją Gradivę, przede wszystkim jednak do Zoe Bertgang, która nie jest biernym przedmiotem męskich zabiegów, lecz - jak zaraz zobaczymy - najpoważniejszą konkurentką ojca psychoanalizy.

Błyskotliwa interpretacja, jakiej Freud poddaje nowelkę, przedstawia się w grubym zarysie następująco. Jego zdaniem wszystko przemawia za tym, że we wczesnym dzieciństwie popęd erotyczny Norberta wyrażał się w dziecięcym uczuciu wobec Zoe Bertgang, następnie jednak - z nieznanych nam przyczyn - uległ radykalnemu wyparciu, wraz z nim zaś wyparte zostały wszystkie wspomnienia i wyobrażenia związane z jedynym obiektem tego popędu, czyli właśnie z Zoe. Rolę czynnika wypierającego, który pilnował, by popęd erotyczny nie wychynął z nieświadomości, pełniła przez lata nauka, dokładniej zaś archeologia: w rezultacie wyparcie to oznaczało całkowite odwrócenie od teraźniejszego życia i pełną koncentrację na tym, co martwe, dawne i kamienne. Opisana w nowelce przygoda Norberta to historia powrotu wypartej erotyki, która - nader przebiegle i paradoksalnie - powraca za pośrednictwem nauki-strażniczki. Zdaniem Freuda taka przebiegłość jest całkiem typowa: „w momencie powrotu wyparte wyłania się właśnie z tego, co wypierające" (s. 109; przekład skorygowany). Innymi słowy, biedny Norbert został podle zdradzony przez archeologię, bo oto poprzez starożytny relief Gradivy zaczęła do niego powracać wyparta erotyka, w szczególności zaś - dziecięca miłość do Zoe Bertgang. Seria snów i urojeń, które poczynają odtąd trapić Norberta, to kolejny przejaw takiej właśnie recydywy wypartej erotyki. Wyjeżdżając do Pompejów, Norbert stara się umknąć przed tym, czego powrót już wyczuwa, zarazem jednak tym bardziej przybliża się do źródła lęku (i obiektu pragnienia). Jego myśli, fantazje, słowa i zachowania naznaczone są odtąd chroniczną dwuznacznością i podwójną determinacją. Na poziomie świadomym odnoszą się do starożytnych Pompejów i postaci Gradivy, na nieświadomym - do całkiem współczesnej Zoe Bertgang. Przykładem jest tu choćby sytuacja, kiedy to podczas snu Norbertowi przychodzi na myśl, że Gradiva żyje współcześnie w swym rodzinnym mieście: z pozoru chodzi o Pompeje, w istocie - o rodzinne miasto Zoe i Hanolda.

W tę gęstniejącą formację obłędną uformowaną w wyniku mściwego powrotu wypartej miłości wkracza „panienka Zoe, ucieleśnienie mądrości i jasności umysłu" (s. 107), którą - jak zaświadczają przytoczone słowa - Freud 
jawnie i słusznie podziwia. Otrząsnąwszy się ze zdumienia wywołanego osobliwym zachowaniem Norberta podczas ich pierwszego spotkania w Pompejach - kiedy to archeolog wziął ją za Gradivę - Zoe postanawia podjąć grę. Zdaniem Freuda zachowuje się przy tym jak rasowa terapeutka: „Nie ma innej drogi; oponując Hanoldowi, zamknęłaby możliwość uwolnienia go. Również podjęta z całą powagą terapia rzeczywistego stanu chorobowego nie mogłaby przebiegać inaczej, jak tylko zrazu na fundamencie obłędu, by zbadać go możliwie jak najdokładniej" (s. 97). Odtąd także Zoe nadaje dwuznaczny charakter swoim czynom i wypowiedziom, zestrajając się z dwuznacznością czynów i wypowiedzi Norberta. Tyle że w jej przypadku owa dwuznaczność będzie, rzecz jasna, świadoma, wykalkulowana i nastawiona na cel, jakim jest „uwolnienie” Norberta. Tu z kolei przykładem może być scena, w której Zoe dzieli się z Norbertem chlebem i mówi: „Wydaje mi się, że już dwa tysiące lat temu siedzieliśmy tak, jedząc chleb. Nie pamiętasz?" (s. 63). Tego rodzaju wypowiedzi bystrej Zoe określa Freud mianem „triumfu dowcipu, który w jednej i tej samej wypowiedzi przedstawia obłęd i prawdę" (s. 154).

Jak wiadomo, sam Freud był zafascynowany archeologią, a co więcej, chętnie przyrównywał pracę psychoanalityka do pracy archeologa. W eseju o Gradivie stwierdza, że „nie sposób znaleźć lepszej analogii dla wyparcia, które zarazem czyni niedostępną i konserwuje jakąś treść psychiczną, niż owo zasypanie w popiołach w tej formie, w jakiej stało się udziałem Pompejów, wskrzeszonych później dzięki pracy odkopywania" (s. 113). Nic dziwnego zatem, że Freud z upodobaniem uwypukla sprytny zabieg, jakiemu Jensen poddaje figurę archeologii. O ile bowiem nominalnie archeologiem jest Norbert, o tyle zagrzebując się w starożytnościach i tam poszukując kobiety swojego życia, sam staje się obiektem, który należałoby odkopać. Jeśli więc Norbert obserwuje cień Gradivy znikającej wśród grobów, także Zoe obserwuje cień Hanolda w analogicznej sytuacji. W rozmowie z przyjaciółką, która niespodziewanie przerwała jej spotkanie z Norbertem, dziewczyna mówi, że chętnie przybyła z ojcem do Pompejów, ponieważ wiedziała, „że coś ciekawego z pewnością uda mi się tu odkopać. Ale na znalezisko, jakie stało się moim udziałem [...] [Zoe oficjalnie odnosi te słowa do spotkania z przyjaciółką, czytelnik wie jednak oczywiście, że chodzi jej o Norberta], nie liczyłabym w najśmielszych marzeniach [= snach]" (s. 66). Freud słusznie kładzie nacisk na ten fragment, podobnie jak i na frazę, w której o Norbercie mówi się jako o "niejako odkopanym z popiołów przyjacielu z dzieciństwa” Zoe (s. 79).

W ujęciu Freuda terapeutyczno-archeologiczna praca, jaką podejmuje Zoe, zostaje zakończona całkowitym sukcesem, Norbert zostaje uwolniony 
od obłędu, odkopany i sprowadzony do teraźniejszości. „Każda terapia psychoanalityczna”, mówi Freud sentencjonalnie, „to próba uwolnienia wypartej miłości" (s. 16o). Podczas tej próby terapeuta wyzyskuje mechanizm przeniesienia, na koniec jednak musi wysupłać się z relacji z pacjentem, ten zaś musi sam poszukać sobie obiektu. Wedle Freuda Zoe miałaby znajdować się w pozycji idealnej, ponieważ ani nie musiała nawiązywać relacji przeniesieniowej - wszakże była dziecięcą miłością Norberta - ani też z relacji z archeologiem nie musi (ani nie chce) się wycofać. Na koniec otrzymuje zatem zdrowego psychicznie, zakochanego w niej człowieka, którego - co lepsze - sama kocha ${ }^{18}$.

„W każdym obłędzie”, pisze Freud, „tkwi ziarno prawdy” (s. 150). Prawdą obłędu Norberta, jego fascynacji Gradivą, jego snów i szalonego przeświadczenia, że na ulicach Pompejów spotyka widmo kobiety zmarłej przed niespełna dwoma tysiącami lat - a zatem prawdą tego wszystkiego byłaby zdaniem Freuda jego miłość do Zoe. To atrakcyjna konstrukcja, a zarazem nader problematyczna. W Goraczce archiwum Derrida nazywa rzecz po imieniu: „Gdy Freud chce wytłumaczyć nawiedzenie archeologa za pomocą logiki wyparcia, w tej samej chwili, w której uściśla, że pragnąłby rozpoznać w tym natręctwie ziarno czy odrobinę prawdy [tj. gdy uznaje prawdę pomieszczoną w tym, co widmowe], zamierza ponownie wydobyć na światło dzienne źródło jeszcze bardziej źródłowe niż źródło widma. Podbijając stawkę, pragnie być archiwistą o wiele bardziej archeologicznym niż sam archeolog. I, oczywiście, co mieściłoby się najbliżej ostatecznej przyczyny, lepszym etiologiem niż powieściopisarz" ${ }^{\prime \prime}$. Derrida ma rację, gdy twierdzi, że problem tkwi

18 Postać Zoe pozostaje w zajmującym kontraście wobec postaci Klary z opowiadania Hoffmanna Piaskun, którym Freud - jak wiadomo - zajmuje się w innym tekście poświęconym kwestiom widmowym, czyli w eseju o tym, co "niesamowite”. Klara (choć sprytnie powołuje się na intelektualny autorytet swojego brata Lotara) jest osobą równie przenikliwą jak Zoe, tak samo też jak panna Bertgang stara się wyrwać ukochanego Nathanaela ze szponów obłędu. Zamiast jednak stanąć zrazu "na fundamencie obłędu", już na samym początku opowieści oferuje trzeźwą (i mądrą) interpretację jego choroby psychicznej, by przekonać się, że prawda może być bezsilna. Wielka szkoda, że - unikając odpowiedzi na pytanie, dlaczego mądra Klara ponosi porażkę - w eseju o niesamowitości Freud w ogóle nie odnosi się do terapeutycznej interwencji ukochanej Nathanaela i jej teorii „tajemniczej potęgi, usiłującej nieustannie oplątać nasze istnienie”, przybierającej kształty "które po większej części bywają tylko własnym naszym obrazem, jakby odbitym w zwierciadle" (E.T.A. Hoffmann Piaskun, przeł. A. Lange, tekst dostępny na stronie https://wolnelektury.pl/media/book/pdf/powiesci-fantastyczne-piaskun.pdf, cytowany fragment: s. 7). Zob. S. Freud Niesamowite, w: tegoż Pisma psychologiczne, przeł. R. Reszke, KR, Warszawa 1997, s. 233-262.

19 J. Derrida Gorączka archwium, s. 141. 
w logice wyparcia, do której odwołuje się ojciec psychoanalizy. Pozwala mu ona wyeliminować widmo hulające po nowelce Jensena i przywrócić linearny porządek czasu, zaburzony w wyniku interwencji owego widma, która prowadzi do dziwnej superpozycji przeszłości i teraźniejszości. Jeśli bowiem cały obłęd Hanolda bierze się stąd, że oto z pewnego dobrze określonego punktu w czasie, z jakiegoś całkiem niewidmowego źródła, powraca do niego wyparta miłość, to podziękowawszy widmom za dostarczenie wiadomości, Norbert może powrócić do normalnego życia. Psychoanaliza może też, pozorując szacunek i braterstwo, triumfować nad literaturą, z której wydobyła właśnie ukrytą prawdę. Ale - czy już to mówiłem? - z widmami nie można uporać się tak łatwo.

O tym, że Freud nie ma całkiem czystego sumienia wobec widm, że coś nie działa w jego interpretacji i że świadomość tego faktu niemal dochodzi do głosu w tekście jego eseju, świadczy najdobitniej sposób, w jaki ojciec psychoanalizy traktuje finałową scenę nowelki Jensena. Gdy młodzi doszli już do porozumienia i mają opuścić ruiny starożytnego miasta, Norbert „osobliwym tonem" prosi ukochaną, by przeszła się chodnikiem. Zoe świetnie wie, o co mu chodzi: „Pogodny uśmiech zrozumienia rozjaśnił usta jego towarzyszki. Zebrawszy nieco lewą dłonią fałdy sukni, Gradiva rediviva Zoe Bertgang, opromieniona spojrzeniem jego rozmarzonych oczu, ruszyła swym spokojnie spiesznym krokiem przez skąpane w blasku słońca płyty na drugą stronę drogi" (s. 79). Freud jest zbyt wytrawnym czytelnikiem literatury, by nie ulec urokowi tej wspaniałej sceny. Oddaje jej sprawiedliwość, w tej samej chwili jednak całe jego odczytanie zaczyna się chwiać. Zapowiadając w swoim streszczeniu ten wielki finał, mówi: „W ten oto sposób piękna rzeczywistość odniosła zwycięstwo nad obłędem, składając jednak hołd temu ostatniemu". A przytoczywszy finałowe słowa nowelki, komentuje: „W chwili owego triumfu erotyki widzimy także to, co było piękne i cenne w obłędzie" (s. 113). Piękna jest więc rzeczywistość i piękny jest obłęd. A raczej tylko był, bo - wedle Freuda - prawda została już zeń wyłuskana, nawracające widmo starożytnej Gradivy przepędzono, pozostała tylko Zoe, czyli współczesne życie. Ale czy naprawdę obłęd i jego widma można tak łatwo odesłać do przeszłości? Czy sam Freud, arcy-przecież-trafnie określając tę scenę mianem „triumfu erotyki", nie przyznaje zarazem, że piękny obłęd wcale nie przeminął, a jedyne został szczęśliwie pożeniony z piękną rzeczywistością? Cóż bowiem stanowi o owym triumfie, jak nie ów cudownie perwersyjny spektakl, w którym współczesna Zoe odgrywa przed ukochanym jego obłędną fantazję, odgrywa Gradivę redivivę i, w nowy sposób, po prostu godzi się nią być? 
Skoro sam tekst daje znać o problemie, spróbujmy nieco skorygować rozwiązanie zaproponowane przez Freuda, posiłkując się jego własnymi kategoriami. Pisząc o częściowo przedstawionych w noweli, częściowo odgadywanych miłosno-napastliwych relacjach Norberta i Zoe w okresie wczesnego dzieciństwa, Freud tłumaczy: „W takiej wzajemnej zależności, w stanie takiego zjednoczenia pobudek czułych i agresywnych, przejawia się niedojrzała erotyka życia dziecięcego - erotyka, której skutki pojawiają się dopiero później, lecz już w formie nieodpartej, i która w latach dzieciństwa jako erotyka widoczna jest tylko dla oka lekarza czy pisarza" (s. 119, przekład skorygowany). Słowo przełożone tutaj jako „później” to nachträglich. Jak już wspominałem, paradoksalna logika Nachträglichkeit, naznaczenia wstecznego, zgodnie z którą późniejsze wydarzenie nadaje kształt i traumatyczną sprawczość wydarzeniu wcześniejszemu, zostanie na dobre wypracowana, nomen omen, dopiero później - a mianowicie podczas pracy nad przypadkiem Człowieka od Wilków. Posługując się tym słowem w eseju o Gradivie, Freud nie ma zapewne na myśli niczego poza zwykłą latencją i opóźnieniem, procesami, które nie zaburzają linearnego porządku czasu. A jednak fakt, że słowo to pada w tym kontekście, wydaje się nader fortunny. Okoliczność ta pozwala nam bowiem uświadomić sobie, że rozumowanie Freuda wymaga w istocie odwołania do logiki Nachträglichkeit. Zarazem jednak, gdy już przywoła się ową logikę na pomoc, rozumowanie to ulega daleko idącej komplikacji, jego egzorcystyczny potencjał zostaje zneutralizowany, widma dostają wreszcie to, co im się należy, a taka dekonstrukcyjna lektura tekstu Freuda owocuje nader zajmującą wizją zespektralizowanego życia.

Otóż jeżeli zarówno przed odkryciem reliefu Gradivy, jak i już po dokonaniu tego odkrycia wspomnienia o dziecięcych relacjach z Zoe pozostają nieświadome (niech będzie: wyparte) i skoro po tym odkryciu zaczynają one oddziaływać, to musimy jakoś odróżnić status tych wspomnień w tych dwóch okresach. Takie odróżnienie umożliwia logika naznaczenia wstecznego. Przyjmując tę logikę, możemy mianowicie powiedzieć, że odnalezienie reliefu wstecznie aktywizuje wspomnienie o Zoe, które odtąd poczyna oddziaływać na psychikę Norberta za pośrednictwem figury Gradivy. Jeśli jednak postawimy sprawę w ten sposób, będziemy też chyba musieli zwrócić uwagę, że nie mamy dostępu do czystego (acz wypartego) wspomnienia o Zoe - nie ma go też Norbert. Spotkanie z reliefem nie tylko nadaje wstecznie przyczynową moc wspomnieniom o Zoe, lecz także w stopniu niemożliwym do wymierzenia współkształtuje ich formę i znaczenie: na tym właśnie polega pełna logika Nachträglichkeit. Nie oznacza to, że Norberta i Zoe nic nie łączyło 
i że całe wspomnienie ich uczucia jest efektem retroaktywnej fantazji. Przyjęcie takiej perspektywy oznaczałoby zgodę na stanowisko Carla Gustava Junga, które Freud tak zajadle atakuje w analizie przypadku Człowieka od Wilków, broniąc realności sceny pierwotnej, a zarazem stopniowo rezygnując z jej szczegółowych określeń. Podobnie jak perspektywa postulująca linearne następstwo wydarzeń, także perspektywa jungowska eliminuje w istocie anachroniczne zaburzenie osi czasu, przeobrażając przeszłość w teraźniejszą fantazję. Zgodnie z prawdziwie anachroniczną logiką Nachträglichkeit w dzieciństwie wydarzyło się, owszem, całkiem sporo, w momencie aktywizacji wszystkie te wydarzenia i wrażenia zrastają się jednak z tym, co je uruchomiło - czyli, w przypadku historii Hanolda, z obrazem Gradivy ${ }^{20}$.

Jeśli przyjmiemy taką perspektywę, będziemy też musieli uznać, że Zoe nie jest obiektem miłości Norberta. Zoe spotkana w dzieciństwie jest przyczynowym bodźcem jego życia erotycznego. Spotkanie z reliefem wstecznie aktywizuje tę przyczynę, tworzy obraz obiektu, a zarazem - rzecz nader istotna - od razu określa go jako utracony. Obiektem miłości Norberta jest postać, którą sam Jensen, a za nim Freud, określają mianem „Zoe-Gradivy”, szczególny kompozyt życia i widma, nierozkładalny na czynniki pierwsze. Zgodnie z logiką, w wyniku której ów osobliwy twór się wyłonił, zaburza on linearny ład czasu: istnieje równocześnie dzisiaj i dwa tysiące lat temu. Skoro zaś, jak trafnie zauważa Derrida w Widmach Marksa, interwencja widma zaburza nie tylko czas, lecz także przestrzen' ${ }^{21}$, Zoe-Gradiva jest również w dwóch miejscach naraz: w rodzinnym mieście Norberta, a zarazem w Pompejach. Jest też po trosze żywa, po trosze martwa, po trosze odzyskana (choć Norbert nigdy jej nie miał!), po trosze utracona, pozostaje żywą istotą, a zarazem ucieleśnionym znakiem utraconej. Sama zresztą całkiem dobrze rozumie swój status, gdy bowiem pod koniec nowelki Norbert, który już całkiem przezwyciężył swój wstręt do italskiej turystyki nowożeńców, proponuje, by w podróż poślubną udali się do Pompejów, Zoe-Gradiva radzi odłożyć tę decyzję na później i wyznaje dowcipnie: „Ja w każdym razie nie czuję się jeszcze dostatecznie żywa, by móc podejmować takie decyzje w sprawach geograficznych" (s. 79). Owo „jeszcze” wydaje się jednak zbędne: nigdy nie będzie w pełni żywa, tak jak nigdy do końca nie opuści Pompejów.

Zob. S. Freud Z historii nerwicy dziecięcej, w: tegoż Dwie nerwice dziecięce, przeł. R. Reszke, KR, Warszawa 2000, zwł. s. 119-144, 185 (gdzie jednak niestety przekład nie oddaje sensu tego kluczowego passusu) i 187. 
W związku z tym inaczej trzeba też spojrzeć na cele terapii, jakiej Zoe poddaje Norberta. Zdrowie, do którego zmierza ten proces terapeutyczny, musi po trosze pozostać skontaminowane przez obłęd, tak jak jawa musi pozostać zaburzona przez sen. Używając metafory archeologicznej, należałoby powiedzieć, że Zoe nie może odkopać Norberta do końca. Nie może też do końca odkopać dla niego samej siebie. Norbert, który w Zoe widzi po prostu uobecnioną Gradivę, jest z pewnością obłąkany - i zakopany. Kim byłby jednak Norbert, gdyby całkowicie uwolnił się od tego obłędu? Raczej nie mógłby kochać Zoe, która nienaznaczona obrazem Gradivy byłaby w najlepszym razie odległym wspomnieniem sympatycznej dziewczynki. Jeśli uleczony Norbert potrafiłby rzeczywiście kochać, zwróciłby się - czego zresztą ewidentnie obawia się zazdrosna Zoe - ku jej przyjaciółce, Gizie Hartleben, ku twardemu, zwykłemu, nienaznaczonemu widmem życiu. Kobieta ta zresztą zwróciła jego uwagę, ponieważ całowała się ze swoim świeżo nabytym mężem - ozdrowieniec nie ma wzorców - jako czysto mimetyczna jego miłość do niej byłaby więc z miejsca i z definicji skazana na porażkę. Zoe musi więc odkopać Norberta i siebie dla niego, ale nie do końca - o ile w ogóle takie kompletne wykopki byłyby możliwe. Musi pozostać żywą kobietą naznaczoną widmowym obrazem Gradivy, on zaś - archeologiem zakopanym w starociach, po części zaś dosłownie widmem błąkającym się wśród grobów: trzeba być widmem, żeby widma kochać. Nie mówiąc już o tym, że Norbert musi pozostać archeologiem także i po to, żeby nie wygasło uczucie, jakim darzy go Zoe. Jak trafnie zauważa Freud, dziewczyna wybrała Norberta na wzór ignorującego ją ojca-uczonego. Norbert, który poświęciłby całą uwagę Zoe, całkiem przestałby ją interesować.

Finałowa scena nowelki, ów „triumf erotyki”, wskazuje, że zarówno Norbert, jak i Zoe akceptują ten cel terapii i własną, częściową spektralizację. O tym, że akceptują także mroczne warunki możliwości swego szczęścia - fakt, że muszą pozwolić na to, by ich życie pozostało skażone śmiercią - świadczy nieco wcześniejsza scena, której Freud, o dziwo, niemal wcale nie dotyka. Idzie mianowicie o pierwszy pocałunek dwojga bohaterów, właściwy moment źródłowy ich związku erotycznego. Oto terapia została już nominalnie ukończona, zazdrosna Zoe radzi Norbertowi, by odszukał Gizę Hartleben - i zbiera się do odejścia. Wówczas to młody archeolog dostrzega szczegół, który odróżnia współczesną Zoe od starożytnej Gradivy. Miałby nim mianowicie być dołeczek na policzku, fałdka, w której zdaje się gromadzić strapienie dzielnej Zoe, a zarazem powstrzymywany, drwiący śmiech. W tym właśnie dołeczku Norbert widzi jakoby jeszcze jedną muchę, obejmuje Zoe 
ramieniem i stara się pochwycić insekta ustami. Ten jednak, jak mu się zdaje, przesiada się na usta dziewczyny, gdzie ściga go Norbert - i tak oto dochodzi do pocałunku.

Ta komiczna scena domaga się uwagi z kilku powodów. Przede wszystkim dlatego, że dołeczek na policzku Zoe to po niemiecku ein kleines Grübchen. To całkiem zwyczajne określenie anatomicznego detalu, dosłownie jednak to mała Grube, czyli dół, lecz także grób. Inaczej mówiąc, tym, co odróżnia pojedyncze, skończone życie od czystej fantazji, od bytu martwego, lecz także od bezwzględnego, absolutnego życia, jest mała fałdka grobu, śmierć wpuszczona w obieg witalności, żałobne wspomnienie po utraconym. Równie istotny wydaje się fakt, że próbując pochwycić iluzoryczną muchę ustami - cóż za dziwaczny pomysł! - Norbert równocześnie stara się zrobić naraz kilka sprzecznych, lecz komplementarnych rzeczy. Po pierwsze: w akcie agresji wyeliminować insekta będącego dlań synonimem natrętnej erotyki; po drugie: dosłownie i ostatecznie go uwewnętrznić, a zatem pogodzić się ze swym popędem; po trzecie: pocałować - czyli chyba zarówno zaakceptować, jak i uwewnętrznić - ów niewielki grób na policzku Zoe. Należy też zwrócić uwagę, że ironiczny sposób, w jaki Jensen prowadzi w tym miejscu narrację, nie pozwala rozstrzygnąć, czy Norbert naprawdę ulega złudzeniu, czy też nie stawiając już oporu popędowi, świadomie podejmuje erotyczną grę. Ostatecznie jednak to rozróżnienie jest właściwie nieistotne. Podobnie jak w przypadku sceny finałowej, gdy dumna Zoe-Gradiva kroczy przed swoim ukochanym, mamy tu do czynienia nie tylko z „triumfem erotyki”, lecz także $\mathrm{z}$,triumfem dowcipu", kiedy to obłęd i prawda wyrażają się w jednym geście, tyle że - inaczej niż przynajmniej oficjalnie twierdzi ojciec psychoanalizy nie sposób ich od siebie oddzielić, tak jak nie można rozdzielić Zoe-Gradivy. Na tym przecież polega dobry dowcip - i dlatego właśnie ostatnie słowa noweli wywołują w nas śmiech radości'i2.

Zgodnie z podpowiedziami Derridy, które starałem się tutaj rozwinąć, Freud wierzył w prawdę widm. Próbował tę prawdę wyłuskać, a następnie wyegzorcyzmować istoty, które ją przekazały. Wiele wskazuje też jednak na

Warto zwrócić uwagę, że Zoe dwukrotnie określa Hanolda mianem szalonego - przy czym w obu przypadkach kluczową rolę odgrywa mucha. Za pierwszym razem Hanold próbuje zabić muchę siedzącą na dłoni Zoe - a tym samym po raz pierwszy dotyka ciała dziewczyny i przekonuje się, że jest ciepłe i żywe. Zoe woła wówczas (zdradzając, że zna imię i nazwisko archeologa): „Jesteś szalony, Norbercie Hanoldzie!” (s. 65). Drugim przypadkiem jest scena pocałunku, podczas której rozmarzona dziewczyna mówi: „Jesteś naprawdę szalony, Norbercie Hanoldzie” (s. 77). Z tego obłędu nie chce go już oczywiście leczyć. 
to, że wiedział albo prawie wiedział, że to nie takie proste - w każdym razie wiedziały o tym jego teksty. Egzorcyzmy Freuda okazują się niezbyt skuteczne i tak jak literatura nie przestaje nawiedzać psychoanalizy, tak też widma nie przestają nawiedzać istot żywych. Nawiedzenie to może oczywiście prowadzić do katastrofy, ale - nie musi. Derrida i Freud przeczytany w duchu Derridy uczą pospołu, że w istocie każde skończone, pojedyncze życie jest życiem nawiedzonym, życiem anachronicznym, naznaczonym widmami nawracającymi z różnych czasów i w różnych cyklach. Te nawroty radykalnie destabilizują żywy podmiot, pozbawiają go suwerenności, wysadzają go z kozła teraźniejszej chwili i nie pozwalają w pełni oddzielić tego, co nasze własne, od tego, co w nas samych i w naszych bliskich jest echem czegoś lub kogoś innego, choćby i nas samych z dawniejszych czasów, kontaminują żywą obecność mimowolnymi i odegranymi pogłosami dawnych słów i gestów. Zarazem jednak - jak pokazuje historia Norberta i Zoe - to one właśnie, gdy nie tworzą jedynej, obłędnej rzeczywistości, lecz interferują z naszym życiem, stanowią paradoksalny warunek możliwości otwarcia na coś nowego, na odzyskanie rzeczy, których nigdy nie mieliśmy, bo nigdy przecież „nie żyły" - Gradiva non vixit - i na to, dziwne, złamane żałobą szczęście, które jako jedyne może stać się udziałem istot żywych. Trzeba wreszcie nauczyć się żyć - czy już to mówiłem? - żyć z duchami. 


\section{Abstract}

\section{Adam Lipszyc}

INSTITUTE OF PHILOSOPHY AND SOCIOLOGY OFTHE POLISH ACADEMY OF SCIENCES

Gradiva non vixit, Or: Living with Ghosts

Lipszyc's point of departure is a philosophy of life as an element inexorably marked by the spectral and anachronistic. Adopting Jacques Derrida's point of view as outlined in Spectres of Marx, Lipszyc presents a detailed analysis of two texts by Sigmund Freud: The Interpretation of Dreams as well as his essay on Wilhelm Jensen's Gradivia. Lipszyc demonstrates that a careful reading reveals the inconsistency between Freud's apparent intentions - his stated goal is to rid life of spectres - and the actual logic of his texts, which tend towards a full and outstandingly interesting spectral philosophy of life. Similarly, the psychoanalytical exorcist is in competition with the writer who seems to accept life with its ghosts.

\section{Keywords}

Jacques Derrida, Sigmund Freud, spectre, dream, life, anachronism 